\title{
Mechanisms of Impaired Water Excretion in Adrenal and Pituitary Insufficiency. IV. Antidiuretic Hormone in Primary and Secondary Adrenal Insufficiency *
}

\author{
C. R. Kleeman, J. W. Czaczkes, $\dagger$ and Ralph Cutler $\$$ with the technical \\ assistance of Ralph Boston \\ (From the Departments of Medicine, Cedars-Sinai Hospitals, Mount Sinai Hospital Division, \\ and the University of California Medical Center, Los Angeles, Calif.)
}

The exact mechanism(s) responsible for the impaired water diuresis of primary and secondary adrenal cortical insufficiency is still unknown. Previous studies from this (1-3) and other laboratories (4-6) have suggested that this defect is due in part to the loss of a permissive effect of cortisol-like steroids on the diluting segments of the nephron, i.e., a normal amount of glucocorticoid is essential to allow maximal impermeability to water to develop in these segments in the absence of circulating antidiuretic hormone (ADH). This concept implies that the release, metabolism, and action of $\mathrm{ADH}$ are normal in the adrenal-insufficient patient (1-3). Others (7-12), however, imply that adrenal glucocorticoids directly affect the release and metabolism of ADH. This implies that the impaired water diuresis of adrenal insufficiency is due to the altered $\mathrm{ADH}$ physiology or its unopposed activity. These conflicting points of view have in general developed from experiments in which the release, metabolism, and action of $\mathrm{ADH}$ were studied indirectly rather than by direct measurement of the hormone in biologic

* Submitted for publication May 11, 1963; accepted April 21, 1964.

Supported by U. S. Public Health Service grant AM06427-01.

Presented at the annual meeting of the American Federation for Clinical Research, Atlantic City, N. J., April 1963.

$\dagger$ From the Laboratory of Clinical Research, Hadassah University Hospital and the Hebrew University-Hadassah Medical School, Jerusalem, Israel ; Celia Davidson Fellow in metabolic and renal diseases.

$\ddagger$ Work done during tenure as U. S. Public Health Service postdoctoral research fellow. Present address: Department of Medicine, University of Washington, Seattle, Wash. fluids. Detection of physiological levels of circulating $\mathrm{ADH}$ can provide direct evidence that may settle this conflict.

In the previous paper (13) the authors have described a sensitive and accurate bioassay for $\mathrm{ADH}$. With this technique it has been possible to study the release, metabolism (turnover), and action of $\mathrm{ADH}$ in untreated patients and animals with adrenal insufficiency. The results conclusively demonstrate that the impaired water diuresis of adrenal insufficiency and its correction by glucocorticoids are not due to an alteration of release, metabolism, or action of $\mathrm{ADH}$.

\section{Methods}

The studies were carried out on patients, dogs, and rats with adrenal insufficiency. The patients, three with secondary and one with primary adrenal insufficiency, took no glucocorticoid replacement therapy for 3 to 5 days before the study. In two males, J.B., age 68 , and G.R., age 47 , the adrenal insufficiency resulted from chromophobe adenomas of the pituitary, whereas in one female, P.S., age 42 , it was secondary to total hypophysectomy for metastatic carcinoma of the breast. One male, A.B., age 43, had Addison's disease, probably due to primary atrophy of the adrenal cortex. In all patients the diagnosis had been unequivocally confirmed by blood and urine measurements of Porter-Silber chromogen before and after administration of ACTH.

A comparable experiment was run on each patient. Water and liquids were withheld for 11 to 12 hours before the experiment. One hour after a light, dry breakfast, an indwelling venous needle was inserted after previous local procaine infiltration and left in place throughout the experiment. After a prehydration sample of blood was obtained, three of the patients drank $1,500 \mathrm{ml}$ of tap water over 10 to 15 minutes. This level of positive balance was maintained throughout the experiment by additional oral ingestion of tap water. In patient P.S. hydration was attained by the rapid iv infusion of $0.45 \%$ sodium chloride, and a positive balance comparable to 
TABLE I

Protocol of water-load experiments in four adrenal-insufficient patients

\begin{tabular}{|c|c|c|c|c|c|c|}
\hline Patient & $\begin{array}{c}\text { Elapsed } \\
\text { time }\end{array}$ & $\begin{array}{l}\text { Blood } \\
\text { sample } \\
\text { no. }\end{array}$ & $\begin{array}{c}\text { Urine } \\
\text { sample } \\
\text { no. }\end{array}$ & $\begin{array}{l}\text { Urine } \\
\text { flow }\end{array}$ & $\begin{array}{c}\text { Osmol- } \\
\text { ality }\end{array}$ & $\begin{array}{l}\text { Plasma } \\
\text { ADH }^{*}\end{array}$ \\
\hline \multirow{14}{*}{ J. B. } & $\min$ & & & $\mathrm{ml} / \mathrm{min}$ & $m O s m / L$ & $\mu U / m l$ \\
\hline & -20 & $B_{0}$ & \multirow[b]{2}{*}{$\mathrm{U}_{0}$} & & 290 & 4.0 \\
\hline & -15 & & & & 710 & \\
\hline & -14 to 0 & & \multicolumn{3}{|c|}{$1,500 \mathrm{ml}$ water orally } & \\
\hline & 10 & $\mathrm{~B}_{1}$ & \multirow{4}{*}{$\mathrm{U}_{1}$} & \multirow{4}{*}{1.46} & 291 & 3.5 \\
\hline & 12 & & & & 640 & \\
\hline & 20 & $\mathrm{~B}_{2}$ & & & 291 & 3.0 \\
\hline & 30 & & & & 280 & 2.0 \\
\hline & 32 & & \multirow[t]{2}{*}{$\mathrm{U}_{2}$} & \multirow[t]{2}{*}{1.3} & 518 & \multirow{4}{*}{1.3} \\
\hline & 40 & \multirow[t]{3}{*}{$\mathrm{B}_{4}$} & & & 287 & \\
\hline & 55 & & $\mathrm{U}_{3}$ & 1.74 & 350 & \\
\hline & 74 & & $\mathrm{U}_{4}$ & 2.32 & 342 & \\
\hline & 80 & \multirow[t]{2}{*}{$\mathrm{B}_{j}$} & & & 290 & \multirow[t]{2}{*}{0} \\
\hline & 92 & & $\mathrm{U}_{5}$ & 2.05 & 307 & \\
\hline \multirow[t]{10}{*}{ G. R. } & -20 & $\mathrm{~B}_{0}$ & & & 296 & 3.5 \\
\hline & -15 & & \multicolumn{3}{|c|}{$\begin{array}{l}\mathrm{U}_{0} \\
1,500 \mathrm{ml} \text { water orally }\end{array}$} & \\
\hline & $\begin{array}{c}-14 \text { to } 0 \\
10\end{array}$ & $B_{1}$ & & (107) wate & 296 & 3.0 \\
\hline & 20 & B. & & & 296 & $\begin{array}{l}3.0 \\
2.5\end{array}$ \\
\hline & 23 & & $\mathrm{U}_{1}$ & 0.36 & 534 & \\
\hline & 30 & $\mathrm{~B}_{3}$ & & & 292 & 1.6 \\
\hline & 40 & $\mathrm{~B}_{4}$ & & & 286 & 1.0 \\
\hline & 43 & & $\mathrm{U}_{2}$ & 2.7 & 499 & \\
\hline & 63 & & $\mathrm{U}_{3}$ & 1.3 & 465 & \\
\hline & 70 & $\mathrm{~B}_{5}$ & I & 162 & 300 & 0 \\
\hline $\mathbf{A}$ & 82 & & $C_{4}$ & 1.02 & $\begin{array}{l}440 \\
307\end{array}$ & 10 \\
\hline A. B. & $\begin{array}{l}-20 \\
-15\end{array}$ & $\mathrm{~B}_{0}$ & $\mathrm{U}_{0}$ & & $\begin{array}{l}307 \\
684\end{array}$ & 4.0 \\
\hline & -15 to 0 & & 1,500 & $\mathrm{ml}$ wate & $r$ orally & \\
\hline & 0 & $\mathrm{~B}_{1}$ & & & 308 & 4.0 \\
\hline & 20 & $\mathrm{~B}_{2}$ & & & 293 & 3.0 \\
\hline & 22 & & $\mathrm{U}_{1}$ & 1.5 & 673 & \\
\hline & 30 & $\mathrm{~B}_{3}$ & & & 293 & 2.0 \\
\hline & 40 & $\mathrm{~B}_{4}$ & & & 299 & 1.3 \\
\hline & 41 & & $\mathrm{U}_{2}$ & 1.7 & 662 & \\
\hline & 61 & & $\mathrm{U}_{3}$ & 1.6 & 660 & \\
\hline & 80 & $\mathrm{~B}_{j}$ & & & 299 & () \\
\hline & 81 & & $\mathrm{U}_{4}$ & 1.5 & 660 & \\
\hline & 91 & & $100 \mathrm{mg}$ & Solu-C & ortef iv $\dagger$ & \\
\hline & 91 & & $\mathrm{~Pa}$ & tient fai & nted & \\
\hline & 116 & $B_{6}$ & & & 297 & 44.0 \\
\hline & 275 & & $\mathrm{U}_{5}$ & 1.05 & 784 & \\
\hline P. S. & -20 & $\mathrm{~B}_{0}$ & & & 305 & 4.0 \\
\hline & -15 & & $\mathrm{U}_{0}$ & & 411 & \\
\hline & 0 & $17 \mathrm{ml} /$ & $\min$ iv $\mathrm{i}$ & nfusion & $(0.45 \%$ & saline in \\
\hline & 10 & $\mathrm{~B}_{1}$ & & 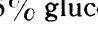 & $\begin{array}{l}\text { ose) } \\
307\end{array}$ & +0 \\
\hline & 18 & $D_{1}$ & $\mathrm{U}_{1}$ & 0.48 & 437 & $\mathbf{4 . 0}$ \\
\hline & 25 & $\mathrm{~B}_{2}$ & & & 295 & 3.0 \\
\hline & 27 & & $\mathrm{U}_{2}$ & 0.69 & 430 & \\
\hline & 40 & $\mathrm{~B}_{3}$ & & & 278 & 2.0 \\
\hline & 55 & $\mathrm{~B}_{4}$ & & & 280 & 1.0 \\
\hline & 57 & & $\mathrm{U}_{3}$ & 0.55 & 420 & \\
\hline & 72 & $\mathrm{~B}_{5}$ & & & 275 & 0.5 \\
\hline & 77 & & $\mathrm{U}_{4}$ & 1.5 & 404 & \\
\hline & 97 & & $\mathrm{U}_{5}$ & 1.65 & 299 & \\
\hline & 100 & $\mathrm{~B}_{6}$ & & & 278 & 0 \\
\hline & 117 & & $\mathrm{U}_{6}$ & 1.8 & 279 & \\
\hline & 130 & & $100 \mathrm{mg}$ & Solu-C & ortef iv $\dagger$ & \\
\hline & 131 & & usion re & duced to & $4.0 \mathrm{ml} /$ & $/ \min$ \\
\hline & 137 & & $\mathrm{U}_{7}$ & 3.2 & 257 & \\
\hline & 157 & & $\mathrm{U}_{8}$ & 2.0 & 258 & \\
\hline & 177 & & $\mathrm{U}_{9}$ & 2.45 & 226 & \\
\hline & 197 & & $\mathrm{U}_{10}$ & 4.25 & 169 & \\
\hline & 217 & & $\mathrm{U}_{11}$ & 5.9 & 121 & \\
\hline & 227 & & $\mathrm{U}_{12}$ & 6.8 & 108 & \\
\hline & 230 & $B_{7}$ & & & 296 & 0 \\
\hline
\end{tabular}

* $\mathrm{ADH}=$ antidiuretic hormone.

$\dagger$ Hydrocortisone sodium succinate, U.S.P., Upjohn Co., Kalamazoo, Mich. the other patients was maintained throughout the experiment. J.B., G.R., and P.S. reclined, while patient A.B. sat in a comfortable lounge chair.

The samples of venous blood obtained in the experiments on man and animals were handled as described in the previous paper (13).

The animal experiments were carried out on six conscious, previously trained dogs (15 to $20 \mathrm{~kg}$ ) and 8 rats (100 to $150 \mathrm{~g}$ ) before and after bilateral adrenalectomy. Rats were adrenalectomized after recovery from their previous bladder exteriorization procedure and maintained on isotonic saline as drinking water for 5 to 10 days until the morning of the experiment; the dogs were maintained on daily $20-\mathrm{mg}$ injections of cortisol and 25 $\mathrm{mg}$ of desoxycorticosterone trimethylacetate every third week. The cortisol replacement was stopped 5 days before an experiment in all dogs. Two of the adrenalinsufficient dogs were used for the $\mathrm{ADH}$ studies.

The dogs were hydrated by stomach tube with a volume of tap water equal to 5 to $10 \%$ of their body weight. This level of hydration was maintained throughout the experiment by the iv infusion of $2.5 \%$ glucose in $0.45 \%$ sodium chloride. The animals reclined comfortably on surgical tables, and urine and blood samples were collected through indwelling bladder catheters and intravenous needles, respectively.

The rat experiments were carried out in a manner identical to the assay procedure described in the previous paper (13). The adrenalectomized rats were decapitated during maximal water diuresis under ethanol anesthesia.

\section{Results}

1) Experiments on man. After 11 to 12 hours of fluid restriction, the levels of $\mathrm{ADH}$ detected in the plasma of these adrenal-insufficient patients ranged from 3.5 to $4.0 \mu \mathrm{U}$ per $\mathrm{ml}$ of plasma ( $\mathrm{Ta}-$ ble I). These concentrations were comparable to those of normal subjects after similar periods of water deprivation (13).

The pattern of response to the sustained water load in each of the patients is tabulated in Table I and illustrated for patients A.B. and P.S. in Figures 1 and 2. Maximal urinary flows and minimal urinary osmolalities attained during the sustained water load ranged from 1.7 to $2.7 \mathrm{ml}$ per minute and from 279 to $300 \mathrm{mOsm}$ per L, respectively. This degree of impairment in maximal water diuresis is comparable to that observed in earlier studies on a larger group of patients with primary and secondary adrenal insufficiency (1).

Despite the marked impairment in diuresis, antidiuretic activity disappeared from the plasma in a manner identical to that of the normal subjects described in the previous paper (13). The 
PLASMA ADH

( $\mu$ units / ml.)<smiles>CCCCC</smiles>

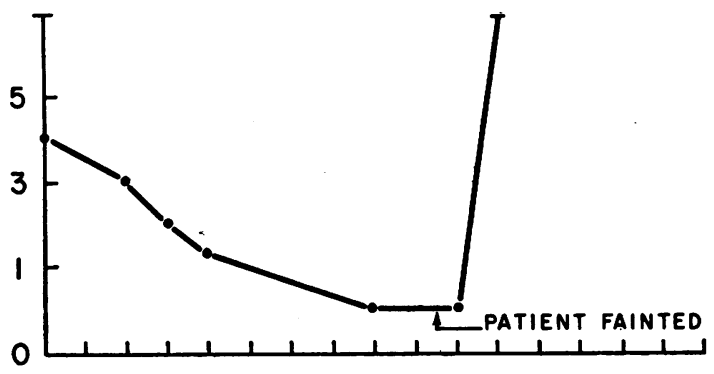

FREE WATER CLEARANCE $(\mathrm{ml} . / \mathrm{min})-1$

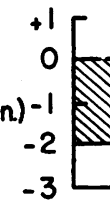

\section{URINE VOLUME}

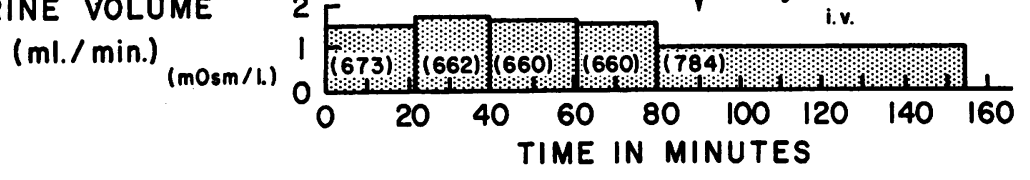

Fig. 1. RElationship BetWeEN THE IMPAIRED WATER DIURESIS AFTer AN ORAL WATER LOAD (1,500 ML) AND THE LEVEL OF ANTIDIURETIC HORMONE (ADH) IN THE PLASMa of a PATIENT With PRimary adRenal insufficiency (A.B.).

PLASMA ADH

( $\mu$ units / $\mathrm{ml}$ )
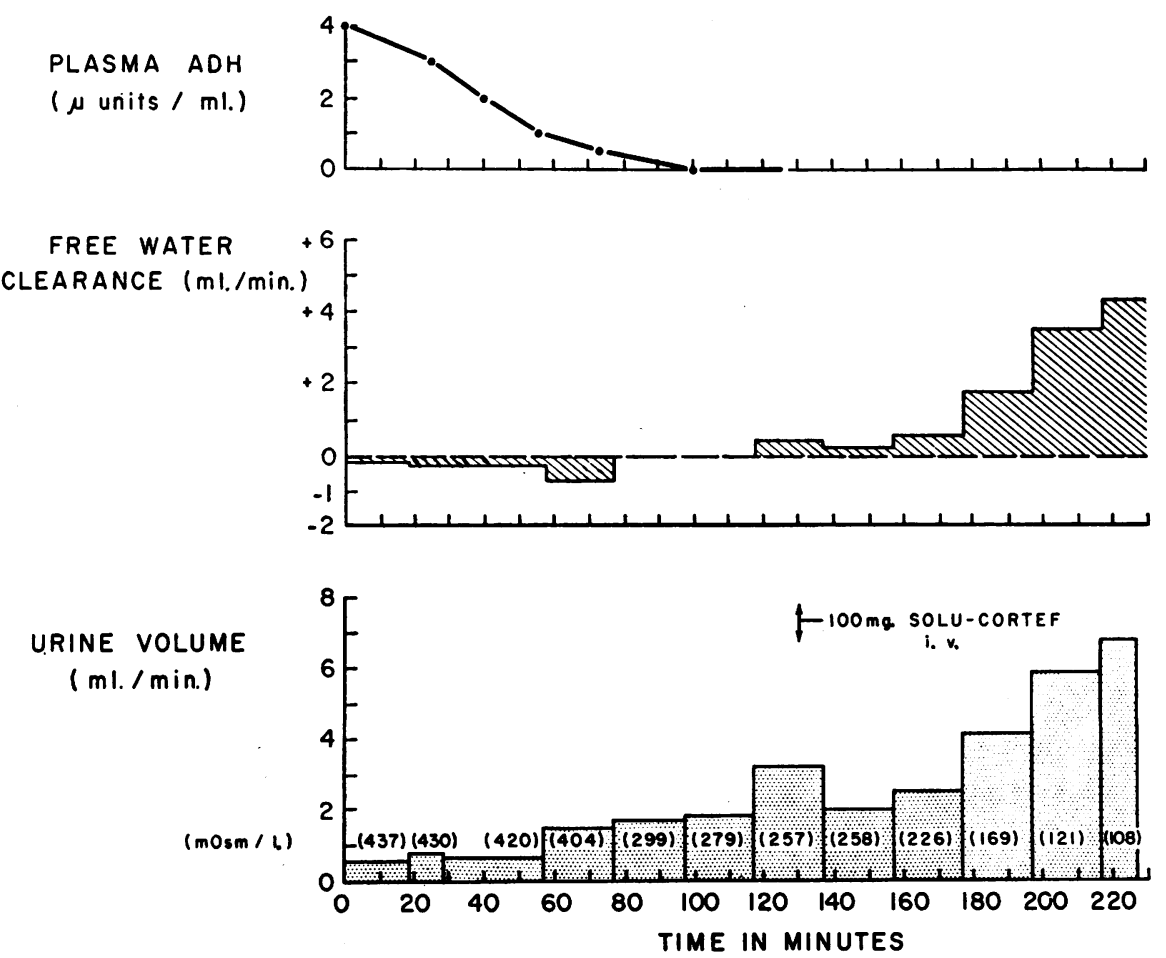

Fig. 2. RELATIONSHiP BETWEen THE IMPAired WATER DIURESis AFTER AN IV WATER LOAD AND THE LEVEL OF ADH IN THE PLASMA OF A PATIENT WITH SECONDARY ADRENAL INSUFFICIENCY (P.S.). 


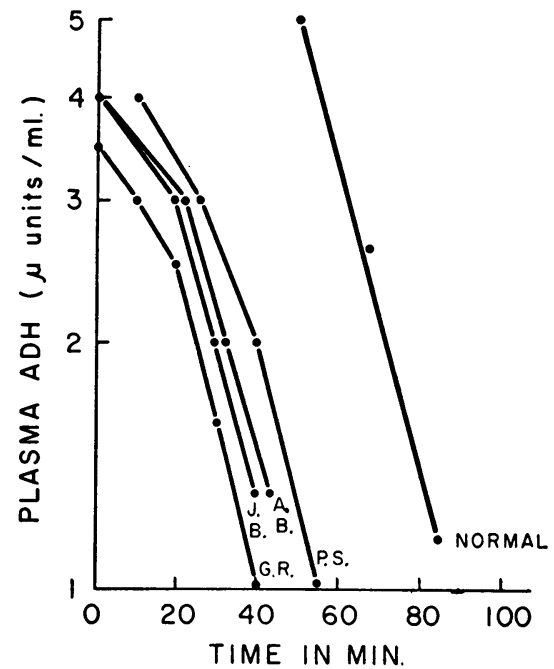

Fig. 3. Semilogarithmic disappearance curves of ADH From the Plasma of patients WITH ADRENAL INSUFFICIENCY COMPARED WITH THE MEAN CURVE OF NORMAL SUBJEcts. The latter represents the second part of the normal disappearance curve. (See ref. 13, Figure 4.)

second part of the semilog disappearance curves of the four patients is compared with the mean curve of the normal subjects in Figure 3. Despite the fact that the latter part of the curve of subject P.S. is drawn through only two points, the similarity of these four curves to the normal is evident. Table II lists the fractional turnover rates and the $t_{\frac{1}{2}}$ of the initial and second parts of the disappearance curves. Although the fractional turnover $\left(\mathrm{K}_{1}\right)$ of the initial part of the disappearance curves of the adrenal-insufficient patient was based on a two-point plot, the curves appear to fit into the pattern observed for the nor-

TABLE II

Fractional turnover rate of endogenous $A D H$ and its half-time as compared to normal controls

\begin{tabular}{ccccc}
\hline \hline Patient & $\begin{array}{c}\text { Plasma } \\
\text { basic ADH }\end{array}$ & $\mathrm{K}_{1} / \mathrm{min}^{*}$ & $\mathrm{~K}_{2} / \min \dagger$ & Half-time \\
\hline & & & & $\min$ \\
Normal & $5.6-18.5$ & & $0.0408-0.0433$ & $16-17$ \\
value & & & & \\
J. B. & 4.0 & 0.0144 & 0.0433 & 16 \\
G. R. & 3.5 & 0.017 & 0.0408 & 17 \\
A. B. & 4.0 & 0.0144 & 0.0433 & 16 \\
P. S. & 4.0 & & 0.0433 & 16 \\
\hline
\end{tabular}

${ }^{*} \mathrm{~K}_{1}=$ fractional turnover rate of the initial part of the disappearance curve.

$+\mathrm{K}_{2}=$ fractional turnover rate of the second part of the disappearance curve.
TABLE III

The effect of adrenalectomy on maximal water diuresis in the dog*

\begin{tabular}{|c|c|c|c|c|}
\hline & $\begin{array}{l}\text { Trine } \\
\text { flow }\end{array}$ & $\mathrm{CH}_{2} \mathrm{O}$ & $\mathrm{C}_{\mathrm{osm}}$ & $\begin{array}{c}\text { Creatinine } \\
\text { clearance }\end{array}$ \\
\hline Dog B., $12.0 \mathrm{~kg}$ & $m l / m i n$ & $m l / m i n$ & $m O s m / L$ & $\mathrm{ml} / \mathrm{min}$ \\
\hline $\begin{array}{l}\text { Preadrenalectomy } \\
\text { Postadrenalectomy } \\
90 \text { minutes after } 50 \\
\text { mg hydrocortisone }\end{array}$ & $\begin{array}{l}3.3 \\
0.6 \\
1.4\end{array}$ & $\begin{array}{r}2.7 \\
-0.1 \\
0.0\end{array}$ & $\begin{array}{r}51 \\
322 \\
281\end{array}$ & $\begin{array}{l}28 \\
17 \\
26\end{array}$ \\
\hline $\begin{array}{l}\text { Dog C., } 14.5 \mathrm{~kg} \\
\text { Preadrenalectomy } \\
\text { Postadrenalectomy } \\
90 \text { minutes after } 50 \\
\text { mg hydrocortisone }\end{array}$ & $\begin{array}{l}5.1 \\
1.5 \\
8.2\end{array}$ & $\begin{array}{l}4.0 \\
0.3 \\
4.8\end{array}$ & $\begin{array}{r}61 \\
225 \\
119\end{array}$ & $\begin{array}{l}56 \\
66 \\
88\end{array}$ \\
\hline $\begin{array}{l}\text { Dog E., } 23.0 \mathrm{~kg} \\
\text { Preadrenalectomy } \\
\text { Postadrenalectomy } \\
90 \text { minutes after } 50 \\
\text { mg hydrocortisone }\end{array}$ & $\begin{array}{r}10.0 \\
1.6 \\
10.7\end{array}$ & $\begin{array}{r}7.9 \\
-0.4 \\
6.7\end{array}$ & $\begin{array}{r}59 \\
378 \\
53\end{array}$ & $\begin{array}{r}106 \\
38 \\
72\end{array}$ \\
\hline $\begin{array}{l}\text { Dog G., } 15.0 \mathrm{~kg} \\
\text { Preadrenalectomy } \\
\text { Postadrenalectomy } \\
90 \text { minutes after } 50 \\
\text { mg hydrocortisone }\end{array}$ & $\begin{array}{l}7.3 \\
5.0 \\
8.6\end{array}$ & $\begin{array}{l}5.8 \\
3.9 \\
6.3\end{array}$ & $\begin{array}{r}61 \\
117 \\
74\end{array}$ & $\begin{array}{l}82 \\
49 \\
75\end{array}$ \\
\hline $\begin{array}{l}\text { Dog 1, } 19.0 \mathrm{~kg} \\
\text { Preadrenalectomy } \\
\text { Postadrenalectomy }\end{array}$ & $\begin{array}{l}8.2 \\
5.5\end{array}$ & $\begin{array}{l}6.7 \\
1.7\end{array}$ & $\begin{array}{r}55 \\
205\end{array}$ & $t$ \\
\hline $\begin{array}{l}\text { Dog } 3,18.4 \mathrm{~kg} \\
\text { Preadrenalectomy } \\
\text { Postadrenalectomy }\end{array}$ & $\begin{array}{l}8.8 \\
3.2\end{array}$ & $\begin{array}{l}6.5 \\
0.2\end{array}$ & $\begin{array}{r}78 \\
288\end{array}$ & $\dagger$ \\
\hline
\end{tabular}

${ }^{*} \mathrm{CH}_{2} \mathrm{O}=$ water clearance; $\mathrm{U}_{\text {osm }}=$ urine osmolality. † Creatinine clearances were not determined.

mal subject dehydrated for less than 24 hours (13).

Patient P.S. received $100 \mathrm{mg}$ of cortisol intravenously after 2 hours of impaired diuresis. Within 1 hour a significant improvement in the water diuresis had occurred, and $2 \frac{1}{2}$ hours after the injection urinary flow and osmolality were $6.8 \mathrm{ml}$ per minute and $108 \mathrm{mOsm}$ per $\mathrm{L}$, respectively (Figure 2). This pattern of improvement in the sustained diuresis after intravenous administration of cortisol is very similar to that previously described $(1,3,6)$.

Patient A.B., whose plasma level of $\mathrm{ADH}$ was zero $(<0.25 \mu \mathrm{U}$ per $\mathrm{ml})$ when his maximal water diuresis was $1.5 \mathrm{ml}$ per minute (Figure 1), developed an episode of syncope 5 minutes after an intravenous injection of cortisol. A plasma sample obtained 20 minutes after this episode, while the patient was reclining, contained $44 \mu \mathrm{U}$ per $\mathrm{ml}$ of antidiuretic activity, a value twice as high as that seen in two normal subjects after $\mathbf{3}$ 
days of dehydration (13). Over the next 4 hours, despite the positive water balance and the cortisol injection, urinary flow was only $1 \mathrm{ml}$ per minute with a urinary osmolality of $784 \mathrm{mOsm}$ per L.

2) Dog experiments. In Table III are listed the levels of the normal and impaired water diuresis in the six dogs and the acute response to intravenous cortisol in four of the animals. The degree of impairment was not generally so great as that observed in the adrenal-insufficient patient, but a consistent impairment of the maximal water diuresis did occur when these animals were retested 5 days after steroid withdrawal. Dogs $\mathrm{B}, \mathrm{C}, \mathrm{E}$, and $\mathrm{G}$ received $50 \mathrm{mg}$ of cortisol intravenously during the impaired diuresis. Ninety minutes later the creatinine clearance and water diuresis had significantly improved in each.

The pattern of water diuresis and disappearance of ADH from the plasma of two of the dogs (1 and 3 ) before and after adrenalectomy are listed in Table IV. The prehydration levels of $\mathrm{ADH}$ before and after adrenalectomy were $6.0 \mu \mathrm{U}$ per $\mathrm{ml}$ and $4.0 \mu \mathrm{U}$ per $\mathrm{ml}$ as compared to $4.0 \mu \mathrm{U}$ per $\mathrm{ml}$ and $5.0 \mu \mathrm{U}$ per $\mathrm{ml}$, respectively. Water was allowed ad libitum before the experiments. Al-

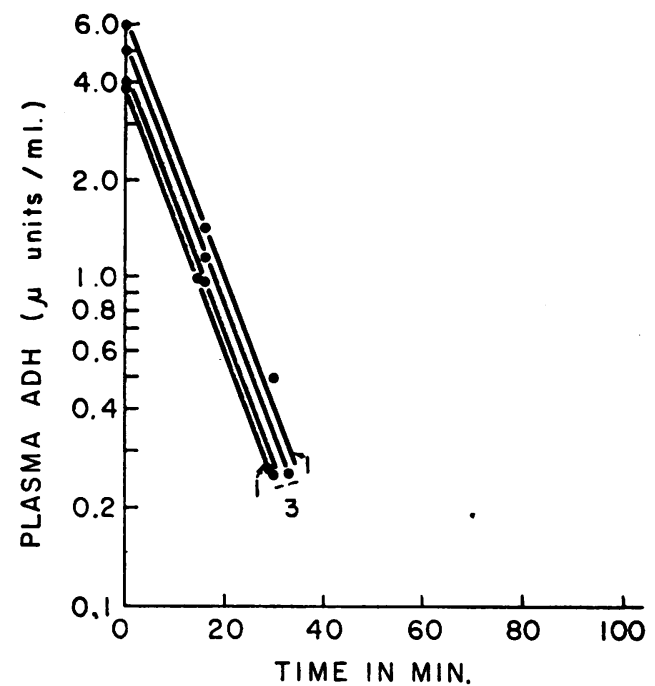

Fig. 4. EFFect of AdRENALECTOMY ON THE DiSAPPEARANCE OF ADH FROM THE PLASMA OF TWO DOGS (No. 1 AND 3) AFTER AN ACUTE WATER LOAD. The abscissa represents the time after administration of the water load.

though in $\operatorname{dog} 3$, before adrenalectomy, urine sample $2\left(\mathrm{U}_{2}\right)$ apparently was still mildly hypertonic when the blood level of $\mathrm{ADH}$ was $0.25 \mu \mathrm{U}$ per $\mathrm{ml}\left(\mathrm{B}_{2}\right)$, possibly $\mathrm{U}_{2}$ was contaminated

TABLE IV

Pattern of comparative water diuresis and ADH disappearance before and after adrenalectomy

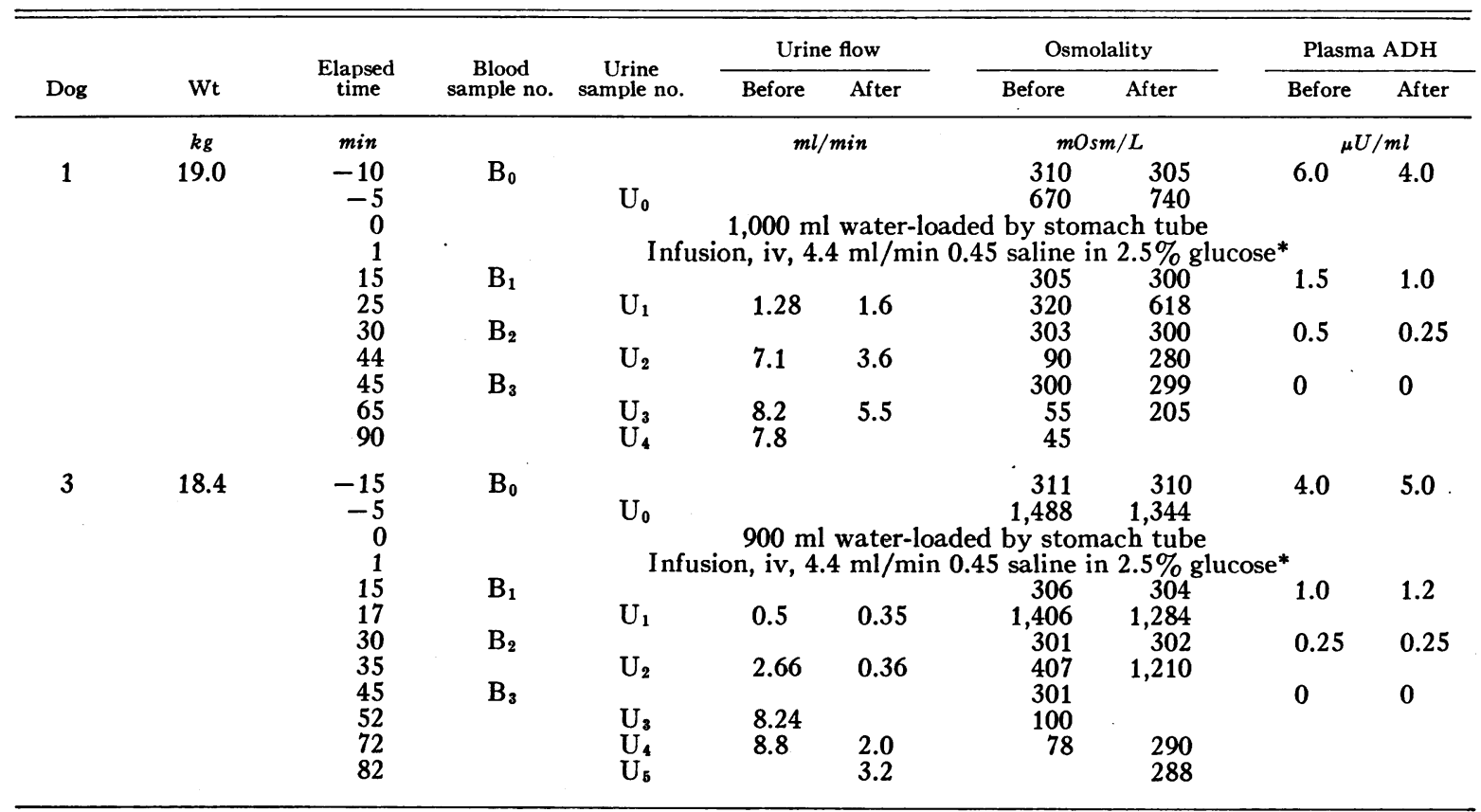

* Only before adrenalectomy. 
TABLE V

Urine flow in four water-loaded rats before and after adrenalectomy*

\begin{tabular}{|c|c|c|c|c|c|c|c|c|}
\hline \multirow{3}{*}{$\begin{array}{l}\text { Dura- } \\
\text { tion of } \\
\text { collec- } \\
\text { tion } \\
\text { period }\end{array}$} & \multicolumn{8}{|c|}{ Urine flow } \\
\hline & \multicolumn{2}{|c|}{ Rat 1} & \multicolumn{2}{|c|}{ Rat 2} & \multicolumn{2}{|c|}{ Rat 3} & \multicolumn{2}{|c|}{ Rat 4} \\
\hline & Before & After & Before & After & Before & After & Before & After \\
\hline $\min$ & \multicolumn{8}{|c|}{ ml/10 minutes } \\
\hline 10 & 1.4 & 0.6 & 1.5 & 0.5 & 1.1 & 0.5 & 1.35 & 0.65 \\
\hline 10 & 1.4 & 0.6 & 1.5 & 0.5 & 1.1 & 0.5 & 1.35 & 0.65 \\
\hline 10 & 1.4 & 0.6 & 1.5 & 0.5 & 1.1 & 0.5 & 1.35 & 0.65 \\
\hline \multicolumn{9}{|c|}{ After $0.35 \mu \mathrm{U}$ of arginine-vasopressin } \\
\hline 10 & & 0.55 & & 0.45 & & 0.45 & & 0.60 \\
\hline
\end{tabular}

* The animals were ethanol anesthetized and hydrated in a manner identical to the assay procedure described in a previous paper (13).

slightly by the very hypertonic urine of the previous sample $U_{1}$. In three normal water-loaded dogs, urine osmolalities of 90,120 , and $110 \mathrm{mOsm}$ per L, respectively, were found while the circulating $\mathrm{ADH}$ level ranged between 0.25 and 0.6 $\mu \mathrm{U}$ per $\mathrm{ml}$. Anaerobic ultrafiltration of the plasma of $\operatorname{dog} 1$, by the technique described in the previous paper (13), before and after adrenalectomy disclosed no binding to plasma protein. Again, despite the impaired diuresis, antidiuretic activity disappeared from the plasma in a manner identical to that observed before adrenalectomy in these two dogs $\left(t_{\frac{1}{2}}=7.5\right.$ minutes, $\left.K=0.0924\right)$. The disappearance curves before and after adrenalectomy are illustrated in Figure 4. In contrast to the human experiments of this and the previous paper (13), no separate initial slope $\left(K_{1}\right)$ was observed in these dog experiments. This may be due to the ad libitum ingestion of water allowed these animals.

3) Rat experiments. No detectable $\mathrm{ADH}$ was present in the plasma of four adrenalectomized rats decapitated during sustained water diuresis and ethanol anesthesia, a finding repeatedly observed in normal rats under similar conditions. In four additional rats maximal sustained water diuresis during ethanol anesthesia was observed before and after adrenalectomy. The degree of impairment is listed in Table V. Antidiuretic activity was not detectable in their plasma despite the impaired water diuresis.
To determine their sensitivity to exogenous $\mathrm{ADH}$, these four rats received 0.1 and $0.25 \mu \mathrm{U}$ intravenously of arginine-vasopressin during the sustained water diuresis. Although no response was obtained after the $0.1 \mu \mathrm{U}$, the $0.25 \mu \mathrm{U}$ caused a reduction of $0.05 \mathrm{ml}$ per 10 minutes in each of the rats (Table V). ${ }^{1}$

Because of the altered renal hemodynamics and solute excretion that are present in the untreated adrenalectomized animal, it is not possible to equate the impaired water diuresis (Table $\mathrm{V}$ ) with the response to a given dose of $\mathrm{ADH}$ in the normal animal (see Table $I$ in reference 13 ), that is, it cannot be stated that a given degree of antidiuresis in the adrenalectomized, water-loaded, ethanol-anesthetized rat is equivalent to a given dose of $\mathrm{ADH}$ in a comparably treated normal animal. Despite this limitation, the response of the four adrenalectomized rats to $0.25 \mu \mathrm{U}$ of $\mathrm{ADH}$ did not suggest an increased sensitivity to the hormone. Therefore, it seems unlikely that their plasma contained an undetectable quantity of $\mathrm{ADH}$ which was responsible for the impaired water diuresis (Table V).

\section{Discussion}

The direct measurements of circulating $\mathrm{ADH}$ in the present study indicate that adrenal insufficiency does not alter the release, turnover, or action of ADH. These measurements confirm the previous conclusions derived from indirect evidence (1-6).

In the adrenal-insufficient man, dog, and rat, water diuresis was significantly impaired despite circulating $\mathrm{ADH}$ levels of less than $0.25 \mu \mathrm{U}$ per $\mathrm{ml}$. Such low concentrations in the normal animal are always associated with a maximal, or near maximal, water diuresis, and adrenal insufficiency does not increase the sensitivity of the nephron to $\mathrm{ADH}$ (see above and ref. 2). Therefore, residual circulating $\mathrm{ADH}$ during the sustained water load is not responsible for the impaired water diuresis of adrenal insufficiency.

\footnotetext{
1 During this experiment, as in the basic assay procedure, urinary volumes are read to the nearest $0.05 \mathrm{ml}$.
} 
What then is the cause of the defective water excretion? Previous studies $(1,3,4)$ indicated that an impaired renal circulation and a decrease in the delivery of solutes and water to the diluting segments of the nephron, while contributing significantly, are not primarily responsible for the impaired diuresis. We can reasonably conclude that glucocorticoids have a specific effect on the permeability of water of certain biologic membranes.

In the animals studied a normal amount of this type of steroid seems necessary for the development of maximal impermeability of the distal nephron to water in the absence of circulating $\mathrm{ADH}$. This would represent a permissive action of cortisol-like steroids. Pharmacologic doses of glucocorticoids can frequently enhance the maximal water diuresis of normal subjects and patients with vasopressin-sensitive and vasopressinresistant diabetes insipidus, without a significant change in renal hemodynamics or solute excretion $(2,4,14-16)$. This suggests an exaggeration of the physiologic effect of these steroids on water transport. It is now necessary to determine the nature of the direct effect of glucocorticoids on the permeability of certain biologic membranes to water.

\section{Summary}

The concentration of antidiuretic hormone $(\mathrm{ADH})$ in the peripheral venous plasma of untreated adrenal-insufficient dogs, rats, and humans has been measured with a sensitive and accurate bioassay. It has been possible to demonstrate that adrenal insufficiency does not alter the release, turnover, or action of ADH. No detectable ADH was present in the plasma of the water-loaded human or animal with adrenal insufficiency despite a markedly impaired water diuresis. $\mathrm{ADH}$ is therefore not responsible for the defective water excretion. These studies strongly suggest that among other possible mechanisms adrenal glucocorticoids have a direct effect on the permeability to water of certain biologic membranes.

\section{Acknowledgments}

We gratefully acknowledge the contribution of Dr. Shun Ling and the technical assistance of Dr. E. Czaczkes and Miss Emma Radler and express thanks to Drs. E. Gold, A. Dashe, and D. Solomon for their assistance in obtaining patients with primary and secondary adrenal insufficiency and to Dr. Irving Lichtenstein for adrenalectomizing the dogs. We gratefully acknowledge the secretarial assistance of Mrs. M. Kauder.

\section{References}

1. Kleeman, C. R., M. H. Maxwell, and R. E. Rockney. Mechanisms of impaired water excretion in adrenal and pituitary insufficiency. I. The role of altered glomerular filtration rate and solute excretion. J. clin. Invest. 1958, 37, 1799.

2. Kleeman, C. R., J. Koplowitz, M. H. Maxwell, R. Cutler, and J. T. Dowling. Mechanisms of impaired water excretion in adrenal and pituitary insufficiency. II. Interrelationships of adrenal cortical steroids and antidiuretic hormone in normal subjects and in diabetes insipidus. J. clin. Invest. 1960, 39, 1472.

3. Cutler, R. E., C. R. Kleeman, J. Koplowitz, M. H. Maxwell, and J. T. Dowling. Mechanisms of impaired water excretion in adrenal and pituitary insufficiency. III. The effect of extracellular or plasma volume expansion or both, on the impaired diuresis. J. clin. Invest. 1962, 41, 1524.

4. Raisz, L. G., W. F. McNeely, L. Saxon, and J. D. Rosenbaum. The effects of cortisone and hydrocortisone on water diuresis and renal function in man. J. clin. Invest. 1957, 36, 767.

5. Welt, L. G., Ed. Essays in Metabolism; the Influence of Disease on the Renal Excretion of Water. Boston, Little Brown, 1957, p. 299.

6. Nabarro, J. D. N. The adrenal cortex and renal function in Modern Views on the Secretion of Urine, F. R. Winton, Ed. London, J. \& A. Churchill, 1956, p. 148.

7. Slessor, A. Studies concerning the mechanism of water retention in Addison's disease and in hypopituitarism. J. clin. Endocr. 1951, 11, 700.

8. Gaunt, R., J. H. Birnie, and W. J. Eversole. Adrenal cortex and water metabolism. Physiol. Rev. 1949, $29,281$.

9. Lloyd, C. W., and J. Lobotsky. Serum antidiuretic substances and urinary corticosteroid in the human. J. clin. Endocr. 1950, 10, 318.

10. Dingman, J. F., and R. H. Despointes. Adrenal steroid inhibition of vasopressin release from the neurohypophysis of normal subjects and patients with Addison's disease. J. clin. Invest. 1960, 39, 1851.

11. Dingman, J. F. Hypothalamus and the endocrine control of sodium and water metabolism in man. Amer. J. med. Sci. 1958, 235, 79. 
12. Gaunt, R., C. W. Lloyd, and J. J. Chart. The Adrenal-Neurohypophyseal Interrelationships in the Neurohypophysis. Proceedings of 8th Symposium of Colston Research Society, H. Heller, Ed. New York, Academic Press, 1957, p. 233.

13. Czaczkes, J. W., C. R. Kleeman, and M. Koenig. Physiologic studies of antidiuretic hormone by its direct measurement in human plasma. J. clin. Invest. $1964,43,1625$.
14. Czaczkes, J. W., and C. R. Kleeman. The effect of various states of hydration and the plasma concentration on the turnover of antidiuretic hormone in mammals. J. clin. Invest. 1964, 43, 1649.

15. Cutler, R. E., C. R. Kleeman, M. H. Maxwell, and J. T. Dowling. Physiologic studies in nephrogenic diabetes insipidus. J. clin. Endocr. 1962, 22, 827.

16. Vesin, P. Etude critique de certains aspects de la physiologie rénale. Presse méd. 1959, 67, 2095. 